\title{
Critical case-studies of non-formal and community learning for sustainable development
}

\author{
Arjen E. J. Wals ${ }^{1,2}$ Yoko Mochizuki ${ }^{3}$. \\ Alexander Leicht ${ }^{4}$
}

Published online: 16 November 2017

(C) Springer Science+Business Media B.V., part of Springer Nature and UNESCO Institute for Lifelong Learning 2017

With the adoption of the United Nations Sustainable Development Goals (SDGs) in 2015, sustainable development is now undoubtedly at the very top of the global agenda. In light of the far-reaching demands sustainable development places on individuals and societies, it is widely acknowledged that education has a key role to play in the pursuit of sustainable development, even though its meaning is not always agreed upon and even contested (Wals and Benavot 2017). What seems clear is that a major change in mindsets and actions is needed for a development that ensures environmental integrity, economic viability and a just society for present and future generations. Education for Sustainable Development (ESD) is generally regarded as a particularly promising approach in this regard. In fact, ESD has been formally included in the SDGs as part of Target 4.7 of SDG 4 on Education:

By 2030, ensure that all learners acquire the knowledge and skills needed to promote sustainable development, including, among others, through education for sustainable development and sustainable lifestyles, human rights, gender

Alexander Leicht

a.leicht@unesco.org

Arjen E. J. Wals

arjen.wals@wur.nl

Yoko Mochizuki

y.mochizuki@unesco.org

1 Department of Social Sciences, Wageningen University, Wageningen, The Netherlands

2 Faculty of Education, Universiy of Gothenburg, Gothenburg, Sweden

3 UNESCO Mahatma Gandhi, Institute of Education for Peace and Sustainable Development (MGIEP), New Delhi, India

4 Section of Education for Sustainable Development and Global Citizenship, UNESCO, Paris, France 
equality, promotion of a culture of peace and non-violence, global citizenship and appreciation of cultural diversity and of culture's contribution to sustainable development (UN DESA DSD 2015).

Furthermore, ESD is also referred to in other SDGs and it can safely be argued that ESD cuts across all 17 SDGs and can indeed be seen as a key instrument to achieve the SDGs (UNESCO 2017).

In order to upscale ESD work globally in the context of the SDGs, the United Nations Educational, Scientific and Cultural Organization (UNESCO), the lead agency for ESD, launched the Global Action Programme on ESD (GAP) at the 2014 UNESCO World Conference on ESD in Aichi-Nagoya, Japan, as a follow-up to the UN Decade of ESD (DESD, 2005-2014). GAP was acknowledged as the follow-up programme to DESD by the United Nations General Assembly in December 2014 (Resolution A/RES/69/211; UN 2014). GAP particularly promotes ESD actions in five areas: (1) policy; (2) education institutions; (3) educators; (4) youth; and (5) local communities.

ESD is generally understood as an education which

empowers learners to take informed decisions and responsible actions for environmental integrity, economic viability and a just society, for present and future generations, while respecting cultural diversity. It is about lifelong learning, and is an integral part of quality education. ESD is holistic and transformational education which addresses learning content and outcomes, pedagogy and the learning environment. It achieves its purpose by transforming society (UNESCO 2014, p. 12).

This is a very ambitious agenda for education, and given the increased complexity and urgency of current sustainability challenges, education and learning-based responses to these challenges will inevitably need to be part of a comprehensive systemic response which also calls for adjustments of legislation, governance and a rethinking of current lifestyles and economic models (UNESCO 2016). What is required is a fundamental reorientation of education at all levels and in all areas of education - not just in formal education, but also in non-formal and informal learning processes. Just like "business-as-usual" is being questioned in light of global sustainability challenges, the same applies to "education-as-usual". There are now well-documented and -researched ESD and related Environmental Education practices in early childhood education (e.g. Hedefalk et al. 2014), primary education (e.g. Green and Sommerville 2015; Laurie et al. 2016) and secondary education (e.g. Laurie et al. 2016). The topic of sustainability in higher education even has its own journal, ${ }^{1}$ which is entering its 19 th volume in 2018, as well as an international handbook dedicated to it (Barth et al. 2015). However, as yet, relatively little is known about ESD in the domain of non-formal education.

Non-formal ESD encompasses a wide scope of learning processes which range from more traditional outdoor learning which provides first-hand experiences of nature to initiatives which aim to help young people become change agents for

\footnotetext{
1 The International Journal of Sustainability in Higher Education; for more information, see http://www. emeraldinsight.com/loi/ijshe [accessed 9 November 2017].
} 
sustainable development and responsible citizenship in their mostly urban communities. Community learning - which encompasses the learning processes by which a whole community moves towards sustainable development - is a particularly interesting area of non-formal ESD which merits further attention and analysis. This special issue on non-formal and community learning for sustainable development presents and analyses a wide range of non-formal ESD practices from different parts of the world (Western Europe, East Asia, Latin America, and Southern Africa). It should be noted that the distinction between formal and nonformal learning is at times artificial and can be critiqued from a sustainability perspective which tends to call for boundary-crossing and making connections rather than distinctions. It is with this in mind that the contributions to this compilation should be read.

This special issue includes seven case studies, some of which are more descriptive and "critically reflexive", while others are grounded in empirical research, or both. We are cognisant of criticisms which have been levelled against case-study research in the field of ESD and are equally aware of the significance of contextual studies of practice which have transformative value both for local practice and practices elsewhere (Walker et al. 2004). We will briefly introduce each of the case studies here and offer suggestions for how they might be linked and what insights they might offer into the practice of non-formal and community learning for sustainable development, which will hopefully inspire further theoretical work and practical actions in this field.

The first three articles cover cases of ESD implementation in cities from developed countries - two from Germany and one from Japan. These are followed by three case studies on learning in community sustainability initiatives addressing specific challenges - youth participation in a sustainability project in Colombia; the use of Information and Communication Technology (ICT) to enhance ecological literacy in Chile; and sustainable agriculture and biodiversity conservation in southern African countries. The seventh article focuses on learning in the network of the Partnership for Education and Research about Responsible Living (PERL).

In discussing the implementation of ESD, whether at international, national, subnational or community level, given the interconnected nature of the challenge of sustainable development, it has become customary to emphasise partnerships and multi-stakeholder co-learning. The first three articles discuss what makes multistakeholder partnerships for ESD effective, while the remaining four articles focus more on the analysis of learning, looking at the targets or beneficiaries of learning interventions.

Japan and Germany, among other countries, have been particular champions of ESD, and the notion of ESD resonates strongly with local stakeholders (see Singer et al. 2017, for Japan). In the first article, entitled "How education for sustainable development is implemented in Germany: Looking through the lens of educational governance theory", Inka Bormann and Jutta Nikel address the implementation process of ESD in Germany during DESD. Based on a meta-analysis of the findings of four related sub-studies they carried out during a three-year project funded by the German Federal Ministry of Education and Research, Bormann and Nikel contribute to the understanding of the process of "transferring" the concept of ESD within a 
multi-level education system. Investigating this process at two levels - the federal state (a sub-national entity in Germany) and the communal level - they detail an emerging "governance regime" (understood as "the specific combinations of principles, norms, rules and procedures guiding the actions in a constellation of actors unique to a certain field or area") in ESD. In the final part of their article, they discuss their findings from the perspectives of theories of transfer and the current empirical basis of ESD policy and governance.

In the next case study, "Mapping a sustainable future: Community learning in dialogue at the science-society interface", Matthias Barth, Daniel J. Lang, Philip Luthardt and Ulli Vilsmaier detail the case of the city of Lüneburg, located in the north of Germany, which was awarded government funding to establish a community learning project to envision a sustainable future ("City of the Future Lüneburg 2030+"). Lüneburg invited a broad range of stakeholders to participate in a community learning process for sustainable development. The authors of this article use the project as a blueprint for sustainable city development. Presenting a reflexive case study, they report on the process and outcomes of the project and investigate community learning processes amongst different stakeholders as an opportunity for transformative social learning.

Similarly, in the third article, entitled "Social learning as a key factor in sustainability transitions: The case of Okayama City", Robert Didham, Paul OfeiManu and Masaaki Nagareo report on an award-winning case from Okayama City in Japan. The Okayama ESD Project is an ongoing initiative in Okayama City, initiated in 2005 as one of the first Regional Centres of Expertise on ESD (RCEs), the secretariat of which is hosted by the Okayama Municipal Government. With a broad participant base of over 240 organisations - community learning centres, schools, universities, NGOs, etc. - , this initiative has run numerous programmes and engaged a large and diverse number of citizens from Okayama City in exploring sustainability issues through collective discussion, envisioning and practice to live more sustainable lives. This article presents the "Okayama Model" as a case of effective social learning for sustainability.

The next two articles are case studies from Latin America and utilise technological tools to promote community learning. In their article entitled "The difference biocultural 'place' makes to community efforts towards sustainable development: Youth participatory action research in a marine protected area of Colombia", Jennifer McRuer and Margarita Zethelius explore the importance of attending to "place" in research methodology to strengthen community efforts towards sustainable development. In the study they carried out in Colombia, they used critical place inquiry to investigate the significance of place particular to youths' lives, through Youth Participatory Action Research - with constitutive components of "photovoice" and "participatory mapping" using software-based Geographic Information Systems (GIS) - to empower youth in learning and action for sustainability. For photovoice, "research participants are provided with cameras and become co-researchers as they use them to capture visual data on research theme(s)". Participatory mapping involves "collaborative processes of map-making to denote community values". McRuer and Zethelius describe how this approach supported youth as co-researchers to examine main research themes of biocultural 
place relationships in connection with well-being and sustainability. They discuss broad implications of this study in terms of how place relations influence research, and how research influences place relations. Local implications include supporting the voice of youth in community efforts to re-imagine and transform place relationships in response to critical place issues such as climate change, top-down resource management, privatisation, commodification and growing environmental injustice.

In "Promoting community socio-ecological sustainability through technology: A case study from Chile", Claudio Aguayo and Chris Eames explore the potential of the use of ICT tools for promoting ecological literacy and action competence among community members in southern Chile. Their case study addressed the ecological deterioration of a lake, with deep social, economic, recreational and cultural implications locally. The authors' research involved developing a theoretical framework for the design, implementation and use of ICT for community learning for sustainability. The framework was based on key ideas from ESD, ICT and community education, and was underpinned by a systems thinking approach to account for the dynamism and complexity of such settings. Activity theory provided a frame to address overarching socio-cultural elements when using technology as a mediating tool for community learning. The authors' findings suggest that the use of an ICT tool, such as a website, can enhance ecological literacy in relation to a local socio-ecological issue.

The next article, entitled "Transgressing the norm: Transformative agency in community-based learning for sustainability in southern African contexts" is by Heila Lotz-Sisitka, Mutizwa Mukute, Charles Chikunda, Aristides Baloi and Tichaona Pesanayi. The authors present four cross-case perspectives of expansive learning and transformative agency development in community-based education in southern Africa, looking at communities which seek to pursue new activities which are more socially just and sustainable. The four cases of community learning and transformative agency focus on: sustainable agriculture in Lesotho; seed saving and rainwater harvesting in Zimbabwe; community-based irrigation scheme management in Mozambique; and biodiversity conservation co-management in South Africa. All four case studies draw on cultural historical activity theory to guide learning and change processes, especially Yrjö Engeström's (2000, 2015 [1987]) third-generation cultural historical activity theory which emphasises expansive learning in collectives across interacting activity systems. The authors extend their analytical focus on agency expressions to probe if and how expansive learning might also facilitate instances of transgressing norms - viewed here as embedded practices which need to be reframed and changed for sustainability to emerge.

The final article in this special issue is entitled "How transformational learning promotes caring, consultation and creativity, and ultimately contributes to sustainable development: Lessons from the Partnership for Education and Research about Responsible Living (PERL) network". Victoria Wyszynski Thoresen investigates three learning approaches about sustainable lifestyles developed by the PERL network. These approaches are structured around core elements of transformative learning for sustainable development, yet focus particularly on the ability to care, consult and be creative. She argues that an almost "magical synergy" 
emerges when learners can articulate their perceptions of sustainable development in relation to their own values and identify how these are actualised in their daily life. What is critical is the understanding of contradictions, interlinkages and interdependencies of modern society. The article concludes by calling for mainstreaming transformational learning for sustainable development in ways which bring forth the "magic synergy of creative caring" - which can potentially foster individuals willing and capable of moving from "business as usual" towards more socially just, economically equitable and environmentally sensitive behaviour.

Some interesting lessons from the articles can be drawn if we distinguish, for analytical purposes, between two ways of conceptualising the implementation of ESD. The first approach emphasises ESD as a global mandate and a shared aspiration governments around the world have subscribed to. In the context of this "policy-driven", more top-down implementation of ESD, different entities ranging from schools, NGOs and enterprises to cities and municipalities - are often recognised for their exemplary ESD practices in order to inspire further practices. The second approach, by contrast, is more bottom-up, starting from grassroots practice. The driving force is to address a concrete and immediate problem on the ground through educational activities. The notion of the "transfer of ESD" in Bormann and Nikel's article suggests that these authors tend towards the first approach, while they are fully cognisant of the importance of meaning-making on the part of different actors adopting ESD. As factors impacting the coordination of action among multiple actors, Bormann and Nikel have identified: (1) the understanding of the normative concept of ESD; (2) the perceived opportunity for actors to gain and increase appreciation within the field of ESD as an incentive for and driver of engagement; and (3) the dynamic quality of the set-up, rules and principles of the coordination of action. This provides interesting guidance for the further upscaling of ESD in learning communities, irrespective of whether these communities are considered locally, nationally, or even at a global level.

The United Nations University's (UNU) global RCE programme is a combination of the first and second approaches. In fact, the RCE programme was conceived as a facilitative mechanism for "social learning" (UNU-IAS 2010). The notion of "social learning" continues to be popular in the analysis of community learning for sustainability. Although social learning has been defined and described in many ways, varying from rather behaviouristic interpretations towards more relational and agency-oriented interpretations, there seems to be a tendency towards the latter perspective. We now understand social learning from an ESD perspective as a collaborative, emergent learning process which hinges on the simultaneous cultivation of "difference" and social cohesion in order to create joint ownership, unleash creativity and the kind of dynamic and energy needed to break with existing patterns, routines or systems. The cases of Lüneburg and Okayama City presented in this special issue provide insights into how various elements of a social learning process can be strengthened to create active learning loops among multiple stakeholders at the city level. It is questionable, however, whether a robust social learning process can be replicated without support - financial and symbolic - from national and/or municipal governments. For the first three articles in this special issue, the significance of the official acknowledgement of model ESD cities 
(whether by the national government or UNU or UNESCO) cannot be ignored. While this gives support to the relevance of global initiatives like DESD or GAP in encouraging ESD activities, it at the same time raises questions about the ownership of community learning initiatives by the local population at large.

It is often the case that policy-driven implementation of ESD initially affects only a minority of local people and does not have immediate impact on the daily lives of the majority, while the assumption is of course that ESD implementation by an initially small set of (local) stakeholders generates further action which eventually affects everyone. The two articles from Latin America presented in this special issue are interesting in this regard. Both case studies emphasise participatory approaches to ensure the ownership of the local population, and the need to attend to the specificity of the local context is one of the key messages which can be gathered from both articles. At the same time, both articles also raise questions on the sustainability of the learning interventions they describe, which seems endangered without dedicated institutional or financial resources for long-term follow up.

The article by Lotz-Sisitka et al. implies that there might be a third way, which is not so much top-down policy-driven or bottom-up local problem-driven, but rather transversal transition-driven. Here actors who are concerned and somehow find each other by chance or by choice or through some form of brokering or facilitation, codefine their concerns and co-create their own solutions, not in a vacuum but in connection with members of governance, NGOs, and education and research networks or organisations. The point here is not so much trying to optimise current practices, by solving a local issue or implementing a policy, but to re-think and redesign them based on alternative, sometimes indigenous, values, assumptions and principles, and to connect these new practices to others elsewhere as part of a social movement.

What also becomes clear from the seven articles presented here is that further research is needed to better understand the notion of transformative learning. The way the different authors of the seven articles use the notion of the transformative varies substantially in the absence of one commonly accepted definition. As LotzSisitka et al. rightly point out, while sustainability education processes are often change-oriented, not enough detail is actually known about how such change emerges from the learning process, or how it contributes to the development of "transformative agency" in community contexts. Two key questions need to be asked in sustainability education, among many others, namely: (1) what is it that needs to be sustained?; and (2) what is that needs to be transformed or even transgressed? The latter question, ironically, is hardly ever asked, even though the notion of transformative learning has become quite popular in ESD circles.

At a time when the role of formal education is often narrowly conceived in instrumentalist terms (UNESCO MGIEP 2017), the emergence of non-formal and community learning for sustainable development as a critical enabler for a transition to sustainability is both urgent and timely. However, the collection of case studies presented in this special issue seems to indicate that much research still needs to be done to understand how we can fill the gap between our stated desire for a more sustainable world and our everyday actions. As Harold Glasser succinctly puts it, "awareness of a problem, accessibility of extensive information on its origins and 
impacts, and even stated concern about it, do not guarantee action" (Glasser 2007, p. 42). Non-formal and community learning for sustainable development, like formal education, should be much more than information transmission, awareness raising, or even the promotion of informed and skilled behaviour - what Paul Vare and William Scott (2007) have called "ESD 1"; it should foster reflexive and active citizenship to shape more sustainable societies which they consider to be "ESD 2". 2

If there is any overall conclusion or pattern which might be drawn from all the contributions to this special issue, it is that boundary crossing is becoming a critical element of learning for, within and from sustainable development. This connects well with Vare and Scott's (2007) notion of ESD 2, but also with the future directions for environmental and sustainability education highlighted in a recent edited volume on this topic by Peter Corcoran et al. (2017). By moving between perspectives, navigating force fields, handling diversity and stepping in and out of one's comfort zone, new possibilities emerge for rethinking how we work, live, connect and organise our lives. This also implies working on topics and themes in more integrated ways, covering the nexus of, say, water, energy, food, health, equity and climate, rather than trying to zoom in on "just" one of those aspects. Similarly, the SDGs can only be meaningfully addressed when viewed in their relationship with each other. Boundary crossing between forms of learning will be necessary as well, blending formal, non-formal and informal forms of learning on the one hand, and, for instance, experiential, social, place-based and ICT-supported learning on the other. The result might be a learning ecology or an ecology of learning, a concept used by George Siemens (2005) which requires the integration of principles explored by chaos, network, complexity and self-organisation theories.

As the target year for the achievement of the 2030 Agenda with its 17 SDGs is approaching, new forms of governance, education, learning and capacity-building will need to be supported which will enable blended forms of learning in vital partnerships between societal actors seeking to live more lightly and equitably on Earth, using their own context (historically, culturally, economically, socially and ecologically) as a starting point. This also means investing in capacity building for boundary-crossing, brokering relationships and building trust and social cohesion, as these processes and properties seem critical for social learning and transformation within communities. The cases featured in this special issue are only a few of many that exist around the world, but most are not researched, documented and shared very well, and herein lies another challenge: making learning towards sustainability in communities more visible and explicit, and finding better mechanisms for sharing them, not just through special issues in a peer-reviewed journal, but also in ways which can more directly inform, or rather, engage, policy and practice.

\footnotetext{
${ }^{2}$ Borrowing from the idea of Web 1.0 and Web 2.0 (one-way communication and two-way sharing of information on the Internet), Vare and Scott (2007, p. 194) refer to ESD 1 to indicate education that promotes and prescribes certain behaviours and ways of thinking that some authority suspects will lead to sustainable development, whereas ESD 2 refers to "building capacity to think critically about [and beyond] what experts say and to test sustainable development ideas" and to "exploring the contradictions inherent in sustainable living".
} 


\section{References}

Barth, M., Michelsen, G., Rieckmann, M., \& Thomas, I. (Eds) (2015). Handbook of higher education for sustainable development. London: Routledge.

Corcoran, P., Weakland, J. and Wals, A.E.J. (2017). Envisioning futures for environmental and sustainability education. Wageningen: Wageningen Academic Press.

Engeström, Y. (2000). Activity theory as a framework for analysing and redesigning work. Ergonomics, 43(7), 960-974.

Engeström Y (2015 [1987]). Learning by expanding: An activity-theoretical approach to developmental research (2nd edition of the 1987 book with a new introductory chapter). New York: Cambridge University Press.

Glasser, H. (2007). Minding the gap: The role of social learning in linking our stated desire for a more sustainable world to our everyday actions and policies. In A.E.J. Wals (Ed.), Social learning towards a sustainable world: Principles, perspectives, and praxis (pp. 35-61). Wageningen: Wageningen Academic Publishers. Retrieved 9 November 2017 from http://edepot.wur.nl/141070.

Green, M. \& Sommerville, M. (2015). Sustainability education: Researching practice in primary schools. Environmental Education Research, 21(6), 832-845.

Hedefalk, M., Almqvist, J., \& Ostman, L. (2014). Education for sustainable development in early childhood education: A review of the research literature. Environmental Education Research, 21(7), 975-990.

Laurie, R., Nonoyama-Tarumi,Y., Mckeown, R., Hopkins, C. (2016). Contributions of education for sustainable development (ESD) to quality education: A synthesis of research. Journal of Education for Sustainable Development, 10(2), 226-242.

Siemens, G. (2005). Connectivism: A learning theory for the digital age. International Journal of Instructional Technology and Distance Learning, 2(1), 3-10.

Singer, J., Gannon, T., Noguchi, F., \& Mochizuki, Y. (Eds) (2017). Education for sustainability in Japan: Fostering resilient communities after the triple disaster. New York and London: Routledge.

UN (2014). Resolution A/RES/69/211 adopted by the General Assembly on 19 December. Follow-up to the United Nations Decade of Education for Sustainable Development (2005-2014): Global Action Programme on Education for Sustainable Development. New York: United Nations. Retrieved 9 November 2017 from http://www.un.org/en/ga/search/view_doc.asp?symbol=A/RES/69/211.

UN DESA DSD (United Nations Department of Economic and Social Affairs, Division for Sustainable Development) (2015). Sustainable Development Goals: 17 goals to transform our world. United Nations Sustainable development knowledge platform [online resource]. Retrieved 9 November 2017 from https://sustainabledevelopment.un.org/.

UNESCO (2014). UNESCO Roadmap for implementing the global action programme on education for sustainable development. Paris: UNESCO. Retrieved 9 November 2017 from http://unesdoc.unesco. org/images/0023/002305/230514e.pdf.

UNESCO (2016). Education for people and planet: Creating sustainable futures for all. Global Education Monitoring Report 2016. Paris: UNESCO. Retrieved 9 November 2017 from http:// unesdoc.unesco.org/images/0024/002457/245752e.pdf.

UNESCO (2017). Education for sustainable development goals: Learning objectives. Paris: UNESCO. Retrieved 9 November 2017 from http://unesdoc.unesco.org/images/0024/002474/247444e.pdf.

UNESCO MGIEP (UNESCO Mahatma Gandhi Institute of Education for Peace and Sustainable Development) (2017). Rethinking schooling for the 21st century: The State of education for peace, sustainable development and global citizenship. New Delhi: UNESCO MGIEP.

UNU-IAS (United Nations University Institute of Advanced Studies) (2010). Five years of regional centres of expertise on ESD. Yokohama: UNU-IAS. Retrieved 9 November 2017 from https://www. rcenetwork.org/portal/sites/default/files/brochures/5\%20years\%20of\%20RCEs.pdf.

Vare, P., \& Scott, W. (2007). Learning for a change: Exploring the relationship between education and sustainable development. Journal of Education for Sustainable Development, 1(2), 191-198.

Walker, K.E., Corcoran, P.B., \& Wals, A.E.J. (2004). Case studies, make-your-case studies, and case stories: A critique of case-study methodology in sustainability in higher education. Environmental Education Research, 10(1), 7-21.

Wals, A.E.J., \& Benavot, A. (2017). Can we meet the sustainability challenges? The role of education and lifelong learning. European Journal of Education, 52(4), 404-413. 


\section{The authors}

Arjen Wals is Professor of Transformative Learning for Socio-Ecological Sustainability at Wageningen University in The Netherlands. Furthermore he is the Carl Bennet Guest Professor in Education for Sustainable Development at IDPP, Gothenburg University and he holds the UNESCO Chair of Social Learning and Sustainable Development. His teaching and research focus on designing learning processes and learning spaces that enable people to contribute meaningfully to sustainability. A central question in his work is: how to create conditions that support (new) forms of learning which take full advantage of the diversity, creativity and resourcefulness that is all around us, but so far remain largely untapped in our search for a world that is more sustainable than the one currently in prospect? Current research focuses on: (1) T-learning in times of climate change; (2) The development of whole-school approaches to sustainability; and (3) Civic science as a means to connect science and society around sustainability challenges. He maintains a blog at www.transformativelearning.nl.

Yoko Mochizuki is Head of the Rethinking Curricula Programme at UNESCO Mahatma Gandhi Institute of Education for Peace and Sustainable Development (MGIEP) in New Delhi. Before joining UNESCO MGIEP in 2015, she was a Programme Specialist at the Section of Education for Sustainable Development, UNESCO, Paris. Before joining UNESCO in 2011, she was an ESD Specialist at the United Nations University Institute of Advanced Studies (UNU-IAS) and conducted policy-oriented and theoretical research on ESD, with a special focus on UNU's major contributions to the United Nations Decade of Education for Sustainable Development (UN DESD), namely Regional Centres of Expertise on ESD (RCE) and Promotion of Sustainability in Postgraduate Education and Research Network (ProSPER.Net). She has published articles in international peer-reviewed journals and written book chapters for edited volumes on social learning for sustainability, international educational cooperation, community learning centres (CLCs), and higher education for sustainable development. She holds an MA from the University of Chicago, USA, and a $\mathrm{PhD}$, with distinctions, in Comparative and International Education from the Graduate School of Arts and Sciences of Columbia University in New York, USA. Prior to joining UNU-IAS, she was Adjunct Assistant Professor at the Department of Human Development, Teachers College, Columbia University, New York.

Alexander Leicht is Chief of the Section of Education for Sustainable Development and Global Citizenship, UNESCO, Paris. Before joining UNESCO in 2011, he was Head of the German Secretariat for the United Nations Decade of Education for Sustainable Development at the German Commission for UNESCO in Bonn. Before joining the German Commission for UNESCO in 2004, he also worked as a university teacher in Hungary and the United Kingdom for three years and originally trained as a teacher, with a graduate degree in literature, at the University of Marburg, Germany, and at the University of Massachusetts at Amherst, USA. He holds a PhD in American Studies from the University of Nottingham, UK. He has published articles and book chapters on Education for Sustainable Development (ESD), Global Citizenship Education, arts education, cultural policy, and other areas of UNESCO's mandate. As Chief of the Section of ESD and Global Citizenship at UNESCO, his current priority is the coordination of the Global Action Programme (GAP) on ESD (the follow-up framework to the UN Decade of ESD) which was launched in 2014 at the UNESCO World Conference on ESD in Japan, as well as the implementation of Global Citizenship Education, including human rights education and the prevention of violent extremism through education. 